\title{
AUTUMN MIGRATION OF PASSERINES IN BAHARIYA OASIS, EGYPT - WHERE DO THEY COME FROM AND WHERE DO THEY GO?
}

\author{
Krzysztof Stępniewski, Matthew L. J. White and Mary Megalli
}

\begin{abstract}
Stępniewski K., White M.L.J., Megalli M. 2011. Autumn migration of passerines in Bahariya Oasis in Egypt - where do they come from and where do they go? Ring 33, 1-2: 27-36. We present the results of studies on directional preferences of passerine migrants in Bahariya Oasis, Western Desert, Egypt. Fieldwork was conducted in August and September 2010. Birds were mist-netted, ringed and tested in Busse's orientation cage; in total 66 tests were analysed. The most pronounced direction was W, which was surprising and remains unexplained. Southern directions were also prominent, particularly SW; among the northern directions NW were distinct and NE less so. Our results are in line with those at other ringing stations in Egypt, suggesting a common migration pattern in this region. They also allow for tracking probable migration routes through Bahariya. Birds may arrive at the oasis from the Nile Delta and Mediterranean coast, then the majority head SW towards Lake Chad, while others may fly directly S or SE towards the Nile Valley. Bahariya Oasis appears to be an important crossing point of passerine migration routes across the Sahara and it is important to continue further studies in this area.
\end{abstract}

K. Stępniewski (corresponding author), Bird Migration Research Station, University of Gdańsk, Al. Marszałka Józefa Piłsudskiego 46, PL-81-378 Gdynia, Poland, E-mail: k.k.stepniewski@gmail.com; M.L.J. White, RSPB Wessex Stone-curlew Project, Enterprise House, Cherry Orchard Lane, Salisbury, SP2 7LD United Kingdom, E-mail: matt.white@rspb.org.uk; M. Megalli, Egypt, E-mail: mary.megalli@gmail.com.

Publication appointed to the SE European Bird Migration Network papers.

Key words: autumn migration routes, directional preferences, Bahariya Oasis

\section{INTRODUCTION}

Every year as many as five billion birds fly from Eurasia to Africa in autumn and back in spring in what is probably the largest and most complex bird migration system in the world (Moreau 1972, Newton 2008). For the majority of migrating populations from central and eastern Europe and western Asia, the main flyway runs 
through the eastern Mediterranean and Middle East. Birds reach Africa in Egypt and then fly southwards across the Sahara Desert (Shirihai 1996, Newton 2008).

Egypt, located in the NE corner of Africa, is one of the most important areas for birds flying the SE route. The country has three main types of environment: sea coasts, the fertile Nile Valley, and deserts that cover about $96 \%$ of Egypt (Goodman and Meininger 1989). After crossing the Mediterranean or Middle East and reaching northern Egypt some birds follow the Nile or Red Sea coast; others, among them many small passerines, fly directly across the Sahara Desert, one of the most inhospitable places in the world, with only a small number of oases as potential stopover sites (Goodman et al. 1986, Biebach 1992).

Studies of passerine migration in Egypt have concentrated mostly on bird strategies for crossing the ecological barrier of the Sahara desert, focusing particularly on fuel accumulation and stopover strategies, as well as non-stop or intermittent flight (Biebach et al. 1986, Biebach 1992, Biebach et al. 2000, Hilgerloh and Raddatz 2009, Yohannes et al. 2009). Relatively few studies have dealt with directions of migration (Kiepenheuer and Linsenmair 1965, Biebach et al. 1991). Since 2001, when the Wadi El Rayan (S of Lake Qarun, Fayoum) ringing station was established, several SEEN (SE European Bird Migration Network) stations have operated in Egypt, recording data on migration dynamics and biometry of passerines (Ibrahim 2011, Ożarowska et al. 2011), as well as on directional preferences, using Busse's orientation cages (Ibrahim 2011). However, these stations operated around the Nile Valley or along coastal areas; until this study none operated in remote oases in the desert (Ibrahim 2011). In autumn 2010 the first SEEN station was established in Bahariya oasis in the Western Desert of Egypt. In this paper we present the results of orientation tests performed there as well as preliminary hypotheses on possible major migration routes through the oasis.

\section{STUDY AREA}

Bahariya Oasis in the Western Desert of Egypt is approximately $280 \mathrm{~km}$ south of the Mediterranean coast and $180 \mathrm{~km}$ west of the Nile Valley, separated from both by expansive areas of arid sand. The oasis forms a depression embedded in the Eocene limestone plateau (lowest point $+80-90 \mathrm{~m}$ a.s.1.), partly encircled by steep escarpments (200-250 $\mathrm{m}$ a.s.1.). The total surface is $1800 \mathrm{~km}^{2}$ (Goodman et al. 1986). There are a number of deep and shallow cased wells, the main source of water in the oasis, as well as several saline lakes, of which the largest is Lake El Marun. Agriculture in the oasis is widespread, with large date palm (Phoenix dactylifera) plantations and substantial areas of alfalfa (Medicago sativa) crops. The small oasis of El Heiz is about $40 \mathrm{~km} \mathrm{SW}$ of the main area of Bahariya, separated by the "Black Desert".

Mist-netting of birds was conducted in two periods: 26-31 August near Lake Abu Yasser in El Heiz and 1-15 September near Lake El Marun in Bahariya Oasis proper (Fig. 1).

Lake Abu Yasser $\left(28^{\circ} 01^{\prime} \mathrm{N}, 2^{\circ} 43^{\prime} \mathrm{E}\right)$ is a small lake located in El Heiz Oasis, $3 \mathrm{~km}$ SE of the Bahariya-Farafra road. The lake edges are marshy and partly overgrown 


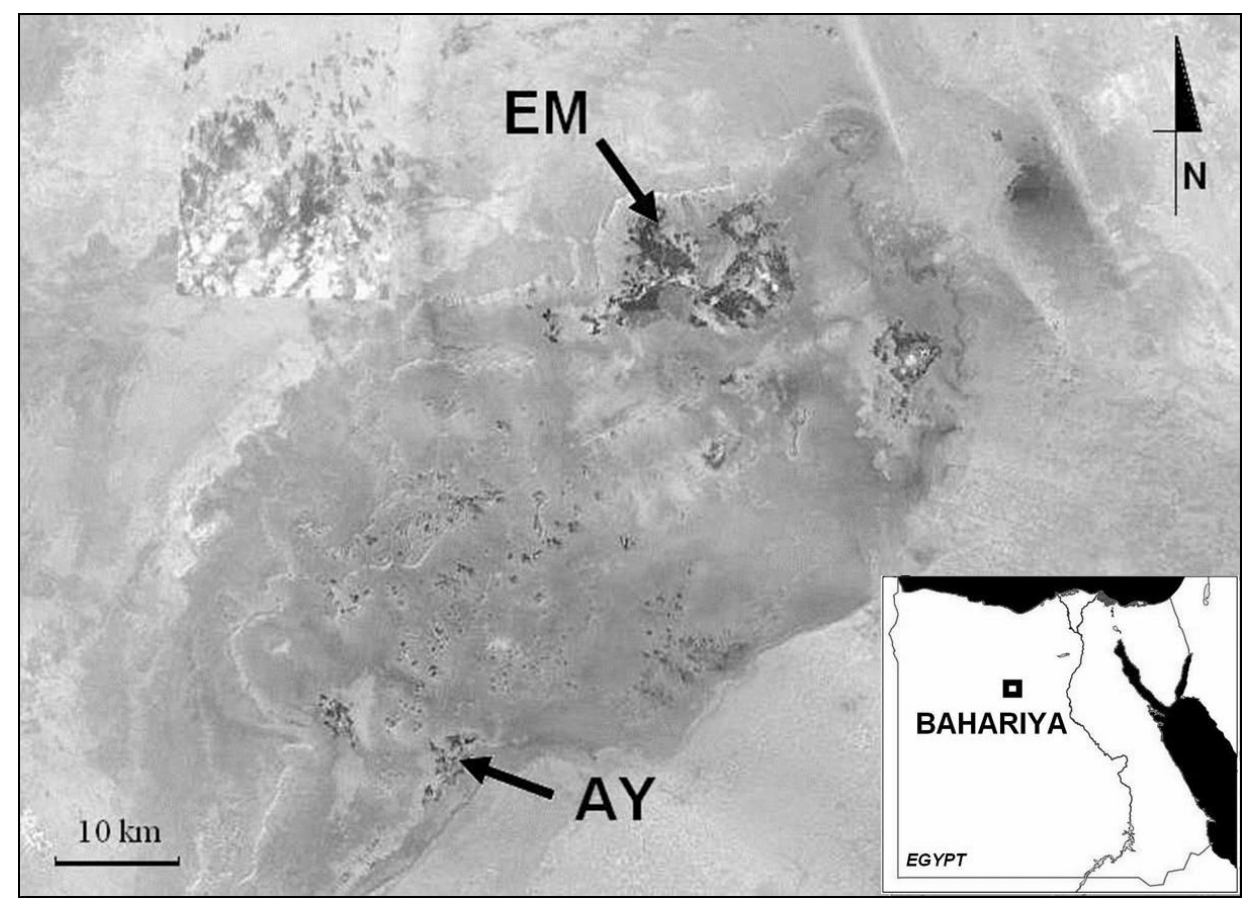

Fig. 1. Bahariya Oasis. The main area of the oasis with Lake El Marun in the upper part of the picture, El Heiz oasis in the lower. Note the escarpments surrounding the depression. Study localities: AY - Lake Abu Yasser, EM - Lake El Marun (source of photograph: GoogleEarth)

with rushes (Juncaceae) and reeds (Phragmites australis). The area beyond the western shore is cultivated with a mosaic of pasture and date palm groves. The lake is surrounded by bare and sandy areas, where only low level vegetation and sparse tamarisk (Tamarix $s p$ ). bushes grow. The nets (10) were placed among the rushes, reeds and tamarisks.

Lake El Marun $\left(28^{\circ} 25^{\prime} \mathrm{N}, 28^{\circ} 53^{\prime} \mathrm{E}\right)$ is a larger saline lake located in the northern part of Bahariya Oasis, $6 \mathrm{~km} \mathrm{~N}$ of the town of Bawiti. In summer, there is less water overflow from wells, which creates large areas of bare, salt-covered ground; in some areas of the lake the edges are overgrown with thin belts of reeds and rushes. Vegetation in the vicinity of the lake is structurally diverse. In areas irrigated by wells, there are date palm groves and alfalfa plantations. Drier areas are sparsely covered with tamarisks, giving way to sandy desert habitats. The study area was situated near the NE shore of the lake. Nets (14) were placed in alfalfa crops watered by the nearby well-fed holding pond, in tamarisk bushes, apricot (Prunus armeniaca) trees and reedbeds. Insects appeared to be very abundant, particularly in alfalfa crops, which attracted many foraging passerine birds. For further details of passerine habitat associations and birds caught at both sites, see White et al. (in prep.). 


\section{METHODS}

Mist-netting was conducted from dawn until 10.00 a.m. and from 4.30 p.m. until dusk; at mid-day temperatures reached around $40^{\circ} \mathrm{C}$ and bird activity was reduced. Caught birds were ringed and a standard set of measurements was taken (fat score, wing formula, wing and tail length; see Busse 2000). After recording the biometrics the birds were tested in Busse's orientation cage. This simple and quick method of testing directional preferences of migrating birds in the field was invented and developed by Busse (for details see Busse 1995). The bird is placed inside a cage constructed of two rounded wires joined by eight vertical sticks; the side wall (divided by the sticks into eight sectors) is covered by transparent foil and the top is covered by netting. The cage itself is placed (always in the same way along the N-S axis) inside a non-transparent rounded screen, so the bird can only see the sky. As the bird tries to escape, it makes indentations and scratches on the foil. After ten minutes the bird is released and the marks on the foil in each sector are counted separately.

The data were analysed with the program ORIENT v. 4.6 using the procedure that allows for multimodal distribution of headings (for detailed description see Busse and Trocińska 1999). Inactive birds (number of scratches lower than 20) and those whose distribution of headings did not differ significantly from randomness (tested by $\chi^{2}$-test) were excluded from the analyses. The results are presented as 16-sector radar graphs based on a compass rose (drawn in Corel Quattro Pro); the headings show the summarized distribution of individual vectors of all the birds from the sample and the polygons are used to make the pictures clearer.

A phenomenon often occurring in the orientation experiments are reverse directions, i.e. opposite to normal direction of migration in a given season (Busse and Trocińska 1999). Two hypotheses explaining them have been postulated (Zehtindjiev et al. 2003): (1) they are reverse directions along the same axis of migration and for analyses they can be safely reversed by adding $180^{\circ}$ (Busse and Trocińska 1999), (2) they reflect directions of arrival. In this paper we follow the second hypothesis and do not reverse the northward directions. This phenomenon requires further studies.

\section{RESULTS}

Altogether 71 orientation tests were conducted; five included inactive birds which were excluded from the analyses. The number of tests was not high (Table 1) due to relatively small numbers of caught birds. Therefore, we only analysed the total distribution of headings for all species (from both stations combined) as well as for the four species with the highest number of tests $(N>6)$.

Western directions were clearly dominant in Bahariya (Fig. 2): W and NW together constituted $47.2 \%$ of all the headings. SW was also distinct (19\%), S and SE less so (14.6 and $9.2 \%$, respectively). The least distinct directions were: NE (4.6\%), $\mathrm{N}(2.9 \%)$ and $\mathrm{E}(2.4 \%)$. 
Table 1

Numbers of orientation tests performed for each species at two study sites; AY - Lake Abu Yasser, EM - Lake El Marun

\begin{tabular}{|l|c|c|c|}
\hline \multirow{2}{*}{} & \multicolumn{3}{|c|}{$N$ of tests } \\
\cline { 2 - 4 } & AY & EM & Total \\
\hline Phylloscopus trochilus & 4 & 12 & 16 \\
\hline Motacilla flava & 0 & 13 & 13 \\
\hline Cercotrichas galactotes & 0 & 9 & 9 \\
\hline Lanius collurio & 4 & 3 & 7 \\
\hline Acrocephalus schoenobaenus & 3 & 2 & 5 \\
\hline Acrocephalus scirpaceus & 0 & 5 & 5 \\
\hline Sylvia curruca & 0 & 4 & 4 \\
\hline Iduna pallida & 1 & 1 & 2 \\
\hline Ficedula albicollis & 0 & 2 & 2 \\
\hline Luscinia luscinia & 0 & 1 & 1 \\
\hline Muscicapa striata & 0 & 1 & 1 \\
\hline Sylvia borin & 0 & 1 & 1 \\
\hline Total & $\mathbf{1 2}$ & $\mathbf{5 4}$ & $\mathbf{6 6}$ \\
\hline
\end{tabular}

Directional preferences for individual species were rather diverse (Fig. 3), but western directions dominated for most, particularly for the Willow Warbler (Phylloscopus trochilus) and the Yellow Wagtail (Motacilla flava). The SW headings were

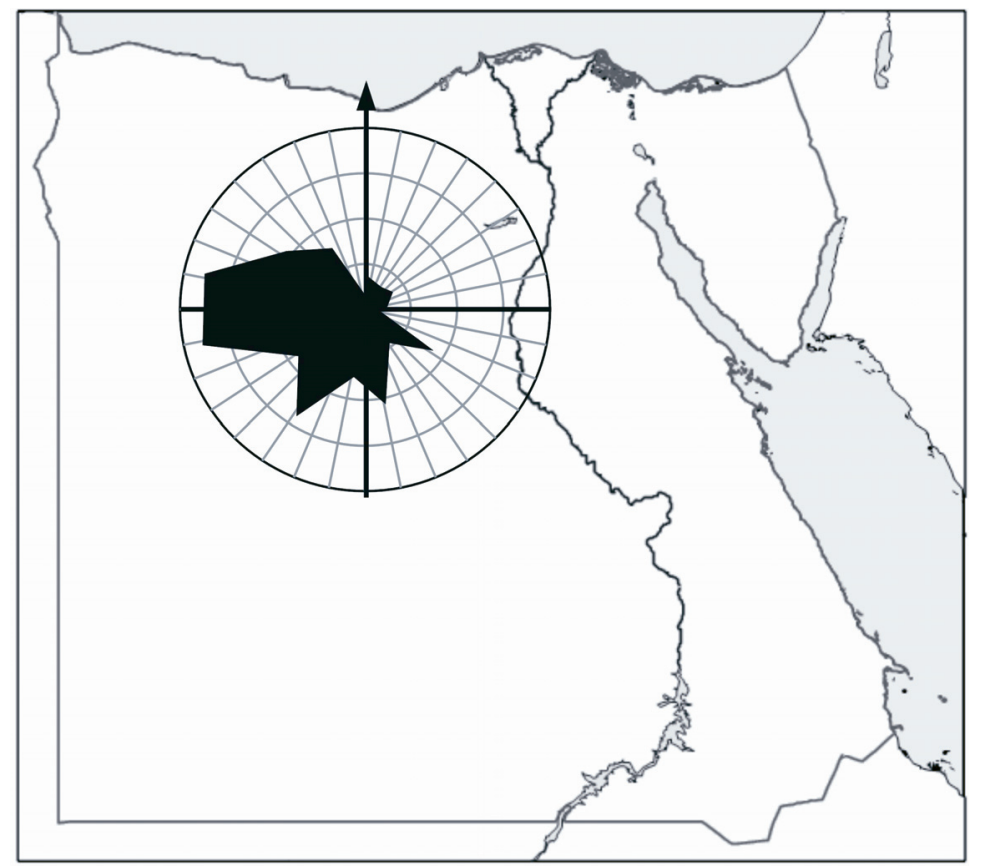

Fig. 2. Summarized distribution of preferred directions of all tested birds (both stations combined) 

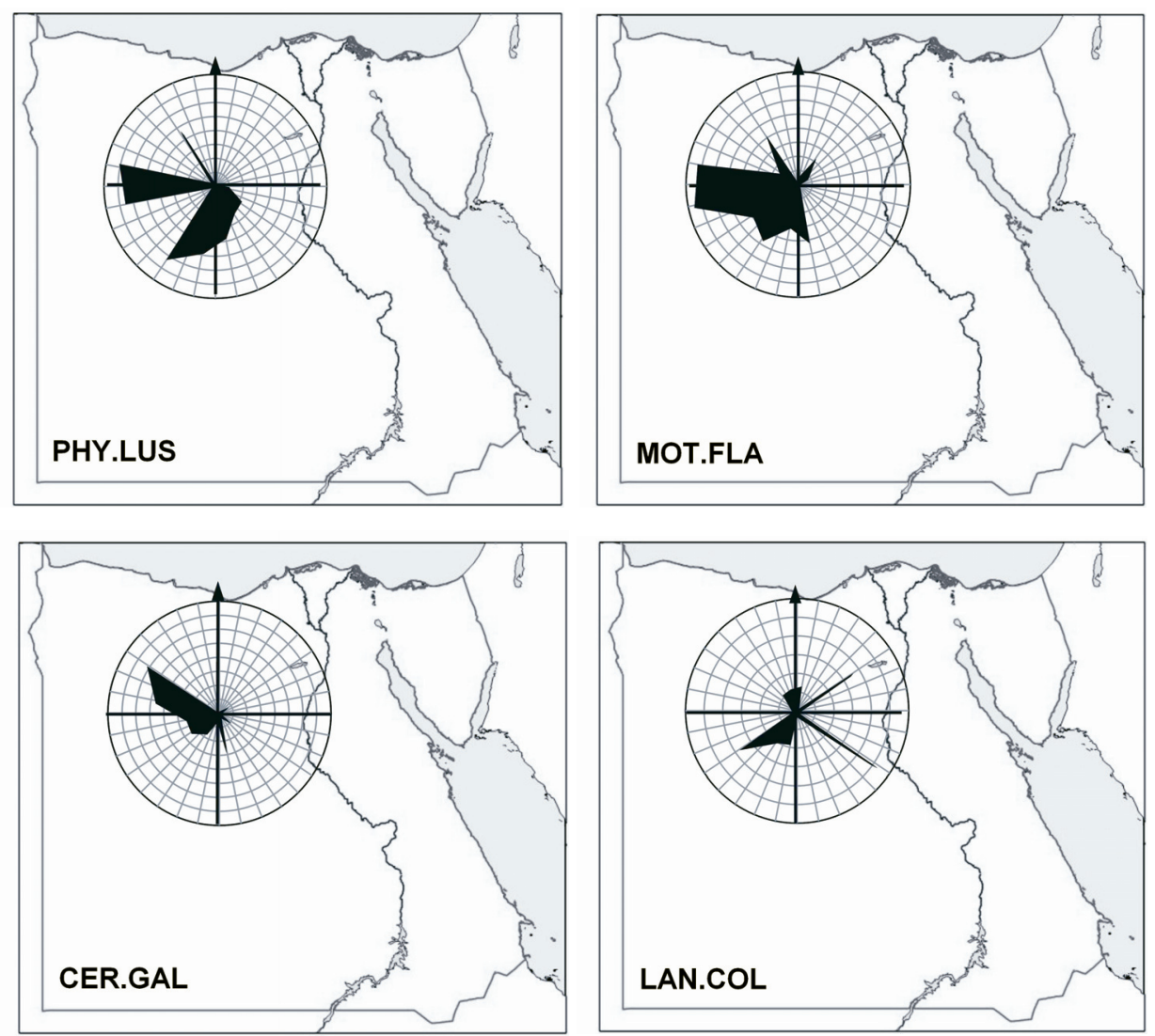

Fig. 3. Distributions of preferred directions for four species with the highest numbers of tests available (both stations combined); PHY.LUS - Willow Warbler, MOT.FLA - Yellow Wagtail, CER.GAL - Rufous-tailed Scrub Robin, LAN.COL - Red-backed Shrike

also strong for all the species except the Rufous-tailed Scrub Robin (Cercotrichas galactotes), for which the NW was the strongest. The SE and NE directions, although subordinate, were also clearly visible, particularly for the Red-backed Shrike (Lanius collurio), but SE also for the Willow Warbler.

\section{DISCUSSION}

Before analysing the results of the orientation experiments in Bahariya, it has to be noted that the number of tests is relatively very low, resulting from low levels of catching. In extensive studies of directional preferences of birds the number of tests should reach at least several dozen or even more (Formella and Busse 2002, Adamska and Rosińska 2006). Also, we did not cover the entire period of migration, which in Bahariya lasts through September and October (Biebach et al. 1986, Goodman and Meininger 1989). Therefore, the results obtained should be treated as rough and preliminary rather than detailed and thorough. 
The western direction was the most prominent heading shown, which was surprising and unexpected. It was pronounced mostly in the Willow Warbler and Yellow Wagtail, which were the species with the highest number of birds tested. This direction is very difficult to explain, as it points directly at the barren desert and is perpendicular to the proper migration axis (N-S). In the W-NW direction, about $300 \mathrm{~km}$ from Bahariya, is another oasis, Siwa. Almost all of the tested species (including the four most numerous) have been seen during autumn migration there (Goodman et al. 1986), but it seems improbable that birds would perform such eastward or westward "jumps" between oases rather than migrate south. Therefore, the western direction remains unexplained and requires further studies. Such unexpected western headings were sometimes noted in Europe as well (Zehtindjiev et al. 2003).

The northern, reverse headings, presumed by us to show the directions of arrival, can be divided into separated groups: NE and NW. The NE headings, although few, are quite visible and probably reflect the direction from the Nile Delta. Their low level is in accordance with results from Azraq Oasis in Jordan, where the proportion of southern, reverse headings during spring migration in 2008 was also very low (Stępniewska et al. 2011). Having just crossed a large ecological barrier, the desert, birds are apparently not eager to go back. In Central Europe there is a lack of serious ecological barriers, therefore the proportion of reverse headings is sometimes quite high (Formella and Busse 2002, Adamska and Filar 2005). The NW headings are more prominent and may reflect flights from the Mediterranean coast. These directions are most pronounced in the Rufous-tailed Scrub Robin. This is the only species tested, apart from the Eastern Olivaceous Warbler (Iduna pallida), that regularly breeds in Bahariya (Goodman et al. 1986). It is possible that local birds could be among the individuals tested and hence the NW headings were influenced by some local unknown factors.

Finally, the southern directions, expected during autumn migration, are quite prominent in Bahariya. They can be divided into three groups: SW, S, and SE. The SW direction, the most pronounced, points presumably to the area around Lake Chad. This large (although recently much shrunken) inland lake, split between Chad, Niger, Nigeria and Cameroon, is an African Important Bird Area, with vast populations of migrant birds (Scholte and Robertson 2001). Almost all of the tested species, except the Thrush Nightingale (Luscinia luscinia), Eastern Olivaceous Warbler and Collared Flycatcher (Ficedula albicollis), have been found at Lake Chad, being common or even (Yellow Wagtail) very abundant (Gustafsson et al. 2003). Moreover, recoveries of Reed Warblers (Acrocephalus scirpaceus) ringed in Austria confirm the occurrence of birds from central Europe (flying the SE route through the Balkans and Egypt) at Lake Chad (Dowsett-Lemaire and Dowsett 1987). Rufous-tailed Scrub Robins (ssp. galactotes, present in Bahariya), on the other hand, were rather rare at Lake Chad (Gustafsson et al. 2003) and this corresponds with a low share of SW headings for this species. Therefore, we presume that the SW direction reveals migration towards Lake Chad. With regard to the two less common southern headings, the SE direction seems to point to the Nile Valley, and the $S$ direction indicates migration southwards across the Sahara to the Sahel. 
The pattern of directional preferences obtained in Bahariya is in accordance with the results from other SEEN stations in Egypt (Ibrahim 2011). At all stations, SW and SE directions are clearly visible, as well as reverse directions NW and NE. At the Wadi El Rayan station, which is the closest to Bahariya, a third, southern direction occurs as well. This suggests a common pattern of nocturnal passerine migration in Egypt. Our results are also consistent with the observations of passage conducted by Biebach et al. (1986) and Biebach et al. (1991) in the Western Desert, where the mean observed direction of migration was S to SW. Observations performed at the Egyptian and Libyan coast of the Mediterranean Sea demonstrated that, in spite of domination of S and SW directions, the SE direction was also prominent (Kiepenheuer and Linsenmair 1965). Thus, birds starting from the coast and heading SE could reach Bahariya. Finally, birds heading $\mathrm{S}$ and SW would have the best wind conditions. In autumn, prevailing winds over the Western Desert blow from the $\mathrm{N}$ and (more to the S) from NE (Erni et al. 2005). Birds flying in the directions mentioned above would benefit most from a tailwind, which is crucial for successful crossing of the Sahara (Biebach 1992, Erni et al. 2005).

We can try to predict possible major migrations routes through Bahariya (Fig. 4). Birds may reach the oasis either from the Nile Delta or from the Mediterranean coast, and the majority then head SW towards Lake Chad. Some birds travel directly southwards, and a minority, presumably only the individuals which travelled from the coast, fly SE to reach the Nile Valley. The western direction still remains a mystery as it is very difficult to find either its source or destination. Overall, it appears that Bahariya Oasis might be an important area of crossing points for passerine migration routes across the Western Desert.

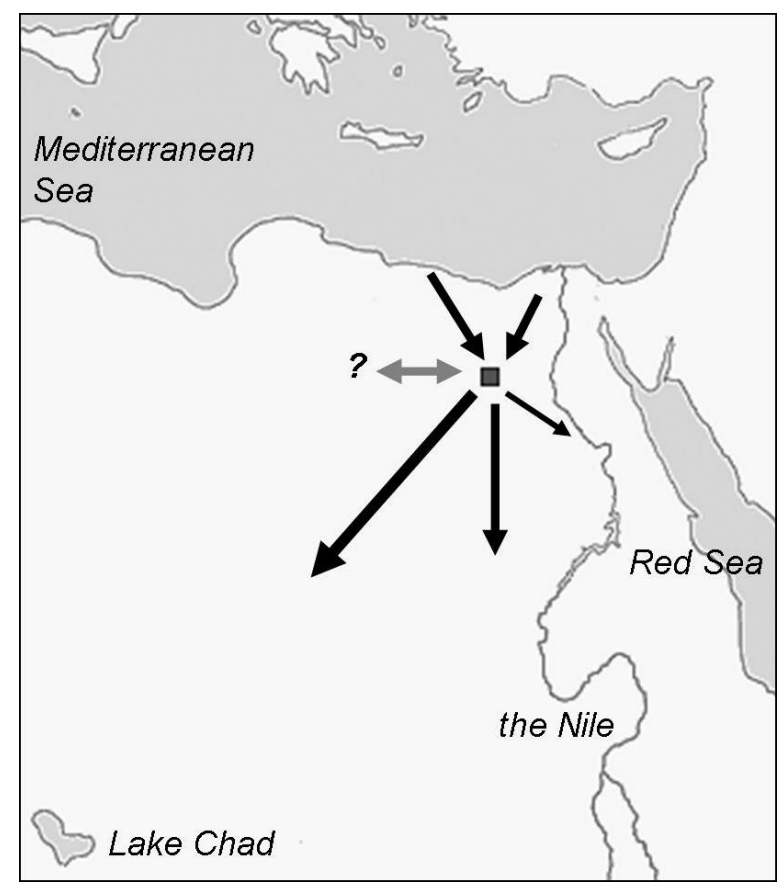

Fig. 4. Possible migration routes through Bahariya Oasis (dark square). Grey double arrow with question mark - "mysterious" western direction (either of departure or arrival). 
Studies of directional preferences of migrants in orientation cages are of great value particularly in areas where ringing recoveries are lacking due to various factors (Ożarowska et al. 2004, Stępniewska et al. 2011). Combining these studies with research on fuelling and stopover strategies would enable us to develop a thorough model describing migration strategies of birds in a given area. Bahariya Oasis is an important stopover area for passerines which rest or refuel during their autumn passage across the Sahara (Biebach et al. 1986). It would therefore be of great importance to continue these studies, possibly through the whole migration period to gather a sufficient sample of data, and focus on variations of preferred directions during the season as well as relations between directional preferences and fuelling and stopover strategies.

\section{ACKNOWLEDGEMENTS}

The authors would like to thank all the people who helped them in their studies, particularly Professor Przemysław Busse, Chairman of SEEN, for his support and valuable comments, Dr Wed A. L. Ibrahim for his help in logistics, and staff and volunteers from Operation Wallacea and Nature and Science Foundation in Egypt who participated in our work. We are also grateful to the Ornithological Society of the Middle East (OSME) for providing a grant to support our research.

\section{REFERENCES}

Adamska K., Filar M. 2005. Directional preferences of the Chiffchaff (Phylloscopus collybita) and the Robin (Erithacus rubecula) on autumn migration in the Beskid Niski Mountains (S Poland). Ring 27, 2: 159-176.

Adamska K., Rosińska K. 2006. Directional preferences of the Robin (Erithacus rubecula) and the Blackcap (Sylvia atricapilla) during autumn migration at Arosio (N Italy) in 2005. Ring 28, 2: 101-111.

Biebach H. 1992. Flight range estimates for small trans-Sahara migrants. Ibis 134: 47-54. DOI: 10.1111/j.1474-919X.1992.tb04733.x

Biebach H., Biebach I., Friedrich W., Heine G., Partecke J., Schmidl D. 2000. Strategies of passerine migration across the Mediterranean Sea and the Sahara Desert: a radar study. Ibis 142: 623-634. DOI: 10.1111/j.1474-919X.2000.tb04462.x

Biebach H., Friedrich W., Heine G. 1986. Interaction of body mass, fat, foraging and stopover period in trans-Sahara migrating passerine birds. Oecologia 69: 370-379.

Biebach H., Friedrich W., Heine G., Jenni L., Jenni-Eiermann S., Schmidl D. 1991. The daily pattern of autumn bird migration in the northern Sahara. Ibis 133: 414-422. DOI: 10.1111/j.1474-919X.1991.tb04590.x

Busse P. 1995. New technique of a field study of directional preferences of night passerine migrants. Ring 17, 1-2: 97-116.

Busse P. 2000. Bird Station Manual. SE European Bird Migration Network, Univ. of Gdańsk, Gdańsk.

Busse P., Trocińska A. 1999. Evaluation of orientation experiment data using circular statistics doubts and pitfalls in assumptions. Ring 21, 2: 107-130.

Dowsett-Lemaire F., Dowsett R. J. 1987. European Reed and Marsh Warblers in Africa: migration patterns, moult and habitat. Ostrich 58, 2: 65-85. DOI: 10.1080/00306525.1987.9634145 
Erni B., Liechti F., Bruderer B. 2005. The role of wind in passerine autumn migration between Europe and Africa. Behav. Ecol. 16, 4: 732-740. DOI: 10.1093/beheco/ari046

Formella M., Busse P. 2002. Directional preferences of the Reed Warbler (Acrocephalus scirpaceus) and the Sedge Warbler (Acrocephalus schoenobaenus) on autumn migration at Lake Drużno (N Poland). Ring 24, 2: 15-29.

Goodman S.M., Meininger P.L. (Eds). 1989. The birds of Egypt. Oxford Univ. Press, Oxford New York.

Goodman S.M., Meininger P.L., Mullié W.C. 1986. The birds of the Egyptian Western Desert. Misc. Publ. Univ. Michigan Mus. Zool. 172: 1-91.

Gustafsson R., Hjort Ch., Ottosson U., Hall Ph. 2003. Birds at Lake Chad and in the Sahel of NE Nigeria 1997-2000. Ottenby Bird Observatory, http://www.sofnet.org/ofstn/apps/Nr\%20181.pdf

Hilgerloh G., Raddatz B. 2009. Weight gains by re-trapped passerine migrants at an artificially vegetated site, Eastern Desert, Egypt. Sandgrouse 31: 57-60.

Ibrahim W.A.-L.A. 2011. General migration pattern and distribution of the passerine birds in different protected areas of Egypt. Ph.D. thesis, Tanta University, Egypt.

Kiepenheuer J., Linsenmair K.E. 1965. Vogelzug an der nordafrikanischen Küste von Tunesien bis Rotes Meer. Vogelwarte 23, 1: 80-94.

Moreau R.E. 1972. The Palaearctic-African Bird Migration Systems. Acad. Press, London - New York.

Newton I. 2008. The Migration Ecology of Birds. Acad. Press, London.

Ożarowska A., Stępniewska K., Ibrahim W. 2011. Autumn and spring migration of the Reed Warbler Acrocephalus scirpaceus in Egypt - some interesting aspects and questions. Ostrich 82, 1: 49-56. DOI: 10.2989/00306525.2010.541502

Ożarowska A., Yosef R., Busse P. 2004. Orientation of Chiffchaff (Phylloscopus collybita), Blackcap (Sylvia atricapilla) and Lesser White-throat (Sylvia curruca) on spring migration at Eilat, Israel. Avian Ecol. Behav. 12: 1-10.

Scholte P., Robertson P. 2001. Chad. In: Fishpool L.D.C., Evans M.I. (Eds). Important Bird Areas in Africa and associated islands: Priority sites for conservation. Pisces Publ. and BirdLife International, Newbury and Cambridge: pp. 177-184.

Shirihai H. 1996. The Birds of Israel. Acad. Press, London.

Stępniewska K., El-Hallah A., Busse P. 2011. Migration dynamics and directional preferences of passerine migrants in Azraq (E Jordan) in spring 2008. Ring 33, 1-2: 3-25.

Yohannes E., Biebach H., Nikolaus G., Pearson D.J. 2009. Passerine migration strategies and body mass variation along geographic sectors across East Africa, the Middle East and the Arabian Peninsula. J. Ornithol. 150: 369-381. DOI 10.1007/s10336-008-0357-z

Zehtindjiev P., Ilieva M., Ożarowska A., Busse P. 2003. Directional behaviour of the Sedge Warbler (Acrocephalus schoenobaenus) studied in two types of orientation cages during autumn migration - a case study. Ring 25, 1-2: 53-63. 